\title{
Cultura y Educación
}

Culture and Education

\section{Online educational videos according to specific didactics: the case of mathematics / Los Vídeos educativos en línea desde las didácticas específicas: el caso de las matemáticas}

\author{
Pablo Beltrán-Pellicer, Belén Giacomone \& María Burgos
}

To cite this article: Pablo Beltrán-Pellicer, Belén Giacomone \& María Burgos (2018) Online educational videos according to specific didactics: the case of mathematics / Los Vídeos educativos en línea desde las didácticas específicas: el caso de las matemáticas, Cultura y Educación, 30:4, 633-662, DOI: 10.1080/11356405.2018.1524651

To link to this article: https://doi.org/10.1080/11356405.2018.1524651

\section{央 Published online: 15 Oct 2018.}

Submit your article to this journal ¿

WII Article views: 137

View Crossmark data $\$ 


\title{
Online educational videos according to specific didactics: the case of mathematics / Los Vídeos educativos en línea desde las didácticas específicas: el caso de las matemáticas
}

\author{
Pablo Beltrán-Pellicer (1) ${ }^{\mathrm{a}}$, Belén Giacomone $\mathbb{0}^{\mathrm{b}}$, and María Burgos $\bullet^{\mathrm{b}}$ \\ ${ }^{a}$ Universidad de Zaragoza; ${ }^{b}$ Universidad de Granada \\ (Received 30 November 2017; accepted 13 September 2018)
}

\begin{abstract}
The vast number of online educational videos available at the moment has generated an emerging area of research concerning their level of suitability. This study considers the epistemic quality of educational videos on mathematics, focusing on the specific content of directly proportional distributions. A qualitative study is used, based on the application of theoretical and methodological tools from the onto-semiotic approach to knowledge and mathematics instruction, principally the notion of epistemic suitability and the identification of algebraic levels. The sample consists of the 31 most popular videos in Spanish on YouTube ${ }^{\mathrm{TM}}$ on directly proportional distributions. Analysis reveals interesting results on these kinds of resources. In general, it is observed that they are weak in epistemic suitability, which does not seem to affect their level of popularity. Moreover, the existence of videos with inaccurate arguments or incorrect procedures, together with the diversity of algebraic levels used, indicates that teachers should be careful when selecting them and only recommend those that better suit their students' needs.
\end{abstract}

Keywords: educational videos; online education; teaching resources; mathematics teaching and learning; didactic suitability

Resumen: Los numerosos vídeos educativos en línea disponibles actualmente están dando lugar a un área emergente de investigación acerca de su grado de adecuación. En esta investigación se estudia la calidad epistémica de vídeos educativos sobre matemáticas, centrando la atención en un contenido concreto, los repartos directamente proporcionales. Se trata de un estudio cualitativo basado en la aplicación de herramientas teóricas y metodológicas del enfoque ontosemiótico del conocimiento y la instrucción matemáticos, principalmente la noción de idoneidad epistémica y la identificación de niveles algebraicos. La muestra está formada por los 31 vídeos en español más populares en YouTube $^{\mathrm{TM}}$ sobre repartos directamente proporcionales. El análisis revela

English version: pp. 633-646 / Versión en español: pp. 647-660

References / Referencias: pp. 660-662

Translated from Spanish / Traducción del español: Julie Waddington

Authors' Address / Correspondencia con los autores: Pablo Beltrán-Pellicer, Área de Didáctica de la Matemática, Universidad de Zaragoza, Facultad de Educación, C/ Pedro Cerbuna, 12, 50009 Zaragoza, España. E-mail: pbeltran@unizar.es 
resultados de interés acerca de este tipo de recursos. En general, se ha identificado que poseen una pobre idoneidad epistémica, aspecto que no parece depender de su popularidad. Así mismo, la existencia de vídeos con argumentos poco precisos o procedimientos incorrectos, unida a la natural diversidad de niveles algebraicos utilizados, sugiere que los docentes deben ser cuidadosos seleccionando y recomendando aquellos vídeos que mejor se adapten a su alumnado.

Palabras clave: vídeos educativos; educación en línea; recursos didácticos; enseñanza y aprendizaje de las matemáticas; idoneidad didáctica

The phenomenon of educational videos hosted on online platforms is not new. Secondary school students, as well as primary students to a lesser extent, spend a good part of their leisure time on social networks, among which they find services and applications where videos are shared. It is therefore natural that they use these productions to help themselves in their studies, and different authors have highlighted that YouTube ${ }^{\mathrm{TM}}$ videos are widely accepted by the student community as a way of learning mathematics (Ramírez, 2010). On the other hand, these kinds of videos are also a widely used resource in certain pedagogical approaches, such as in 'flipped learning' (Davies, Dean, \& Ball, 2013).

The availability of online resources that support mathematics learning means that many students visit these online sites before consulting their teacher. This poses questions concerning how resources are organized to facilitate access and how they are pedagogically designed to increase conceptual understanding (Borba et al., 2016, p. 606). Specific didactics therefore need to carry out studies on the level of suitability of these teaching/learning proposals, thereby ensuring that technology is in line with learning objectives (Turney, Robinson, Lee, \& Soutar, 2009, p. 80).

In this sense, some studies describe the design and implementation of tutorials. In this regard, Márquez (2002) suggests creating multimedia tutorials to facilitate the learning of concepts related to statistics. While Márquez advocates the need to design videos rich in mathematics content, he does not assess the epistemic suitability of the resource, merely pointing out the positive effects on aspects related to users' motivation and attitude (affective facet). Arguedas and Herrera (2016) use a survey with a group of students to assess tutorials from a YouTube $^{\mathrm{TM}}$ channel, focusing on audiovisual aspects, content and instruction. Regarding content, although the results allude favourably to the variety of representative problems, to connections between the topics taught and to the use of different strategies, students suggest that the material could be improved by including a good number of exercises for each topic.

While various studies have contributed to research on the use of educational videos, the results obtained regarding the type of problem-solving and mathematical content exhibited are scarce, although studies along these lines are starting to be published (Ruiz-Reyes, Contreras, Arteaga, \& Oviedo, 2017; Santos, 2018). In view of this, this study describes and interprets the epistemic facet of previously selected online educational videos, with the general objective 
being to assess the degree of epistemic suitability of the most watched videos by YouTube ${ }^{\mathrm{TM}}$ users.

\section{Didactic suitability}

A qualitative methodology within an interpretative and assessment framework has been adopted in this study, supported by theoretical and methodological tools from the ontological-semiotic approach to knowledge and mathematics instruction (OSA) (Godino, Batanero, \& Font, 2007). From this research approach to mathematics education, didactic suitability is defined as the degree to which an instruction process includes certain characteristics that enable it to be qualified as a suitable means of adapting the personal meanings obtained by students (learning) to institutional meanings, whether these are intended or implemented (teaching), considering the influence of the context (Godino, 2013). This involves the coherent and systemic articulation of six facets (Godino et al., 2007, p. 133): epistemic, ecologic, cognitive, affective, interactional and mediational. For each of these, Godino (2013) proposes a system of general criteria for them to be considered of sufficient quality. These didactic suitability criteria are powerful tools for organizing reflection and assessment of instruction processes (Breda, Pino-Fan, \& Font, 2017, p. 1,893), and it is therefore useful to use them a priori to analyse and assess the videos of the sample under consideration. In line with this final aspect, Santos (2018) proposes a model to assess educational mathematics videos available on the Internet, considering three components: the notion of didactic suitability established in the OSA, the fuzzy logic for considering the assessment through the opinion of communities of interest and multicriteria methods (TOPSIC), to order the data obtained and make decisions based on them.

\section{Epistemic facet}

This study focuses on the epistemic facet of online educational videos, which refers to the teaching of 'good mathematics' (Breda et al., 2017, p. 1,898). Epistemic suitability is considered high when the intended or implemented contents cover the reference contents adequately. Thus, in order for an observed teaching process to be considered good quality, two basic criteria should be taken into account (Godino, 2013):

- The presence of different meanings of the corresponding content and their interconnection.

- Recognition of the diversity of the primary objects and processes involved for the different meanings.

Within the OSA framework, situations and problems play a central role, insofar as mathematics objects participate and emerge from the mathematical practices (actions carried out by a subject to solve a problem). From this onto-semiotic perspective, 
mathematics activity can be described and analysed on the basis of an explicit typology of objects which interact between each other, creating a network of knowledge. Depending on their nature and function, these primary entities are classified into the following categories (Godino et al., 2007):

- Languages (in their different registers and representations, natural, gestural, symbolic, graphic, etc.).

- Situations-problems (intra- and extra-mathematics applications, exercises, problems).

- Rules:

- Concepts-definition (concepts introduced through definitions or descriptions, proportionality, function, etc.).

- Propositions (statements about concepts-definition).

- Procedures (algorithms, operations, calculation techniques).

- Arguments (statements used to validate or explain propositions and procedures).

Applying didactic suitability means delimiting the object of study in order to ensure richer specific analyses. In this case, the focus of attention is on a very specific area of content which appears in a specific part of the curriculum: directly proportional distributions. This kind of situation-problem appears in the first stage of secondary education in Spain, within the block dedicated to 'Numbers and algebra' of the LOMCE (Spanish Education Act) and the autonomous community curricula specifications included in the second year of secondary school (13-14 years old). Proportionality is also a recurrent theme on the educational channels found on YouTube ${ }^{\mathrm{TM}}$.

Focusing attention on directly proportional distributions also enables us to use the school algebraic reasoning model proposed in the OSA approach to analyse certain components of epistemic suitability. The model in question identifies different levels of the algebrization of mathematics practices that are carried out to solve tasks set in primary and secondary education (Godino, Aké, Gonzato, \& Wilhelmi, 2014; Godino et al., 2015). These levels are defined considering the types of representations used, the generalization processes involved and the analytical calculation carried out in the corresponding mathematical activity, in such a way that the three first levels are sufficient for our study.

\section{Materials and method}

\section{Sample}

Among the Internet platforms that host free-access videos, we focus here on YouTube $^{\mathrm{TM}}$, since it is the 'leader of Internet videos in many countries of the world, including Spain' (Camacho \& Alonso, 2010, p. 159). A search for videos on YouTube ${ }^{\mathrm{TM}}$ with the keywords 'proportional distribution' produces 1,370 results. In order to consider the most popular videos on the Net, only those with over 1,000 views have been selected. In this way, the total number is 
reduced to 60 videos. Of these, approximately half focus exclusively on inverse or compound proportional distributions, in such a way that the final sample of the study is made up of 31 videos, listed in Table 3 of Discussion and conclusions.

\section{Method}

\section{Baseline meanings}

Studies carried out in the context of OSA (Burgos, Giacomone, Beltrán-Pellicer, $\&$ Godino, 2017) have developed interpretations of the meanings of the proportional object in terms of the systems of practice carried out to solve certain kinds of situations and problems that can be easily adapted to the case of directly proportional distributions:

- Level 0 solutions: arithmetic meaning. This is characterized by the application of arithmetic calculation procedures (multiplication, division) and the absence of algebraic objects and processes.

- Level 1 solutions: proto-algebraic meaning. Ratios and proportions are used as objects of a second level of generalization. The generality of intensive objects is recognized through natural, numerical and iconic language, which is different from symbolic-literal language, and the relations and properties of operations are applied. Examples of this kind of reasoning are 'part-whole' solutions, which use fractions as operators; the unitary method, where we find unitary ratio and certain kinds of diagrammatic solutions.

- Level 2 solutions: proto-algebraic meaning. The situation is proposed as a problem of missing value involving an unknown and the arrangement of an equation that can solve it, ideally, through the method of ratio equivalences. Sometimes, this kind of solution is known as 'the rule of three', although it frequently appears in a degenerated form, i.e., without referring to the meanings of the objects involved.

- Level 3 solutions: algebraic meaning. Symbols are used in an analytical manner, without referring to the context, and operations with indeterminates of variables are carried out to obtain simplified forms of the expressions involved.

\section{Coding and assessment procedure}

Each video was coded according to the indicators proposed for epistemic suitability by Godino (2013), discounting those that lacked meaning in this study, since they adopted a one-way approach and were not framed within a didactic sequence a priori. For example, it does not make sense to assess whether the sample of situations and problems is varied and representative since, normally, educational videos only present one situation. Therefore, the indicators considered were those shown in Table 1. 
Table 1. Coding scheme according to the components of epistemic suitability.

\begin{tabular}{|c|c|}
\hline & Registers and representations \\
\hline Languages & Suitability of the level of language used \\
\hline $\begin{array}{l}\text { Rules (definitions, propositions and } \\
\text { procedures) }\end{array}$ & $\begin{array}{l}\text { Clarity and correction. } \\
\text { Rules are suitable for the level. }\end{array}$ \\
\hline $\begin{array}{l}\text { Arguments (explanations, } \\
\text { verifications, demonstrations) }\end{array}$ & $\begin{array}{l}\text { Clarity and correction. } \\
\text { Arguments are suitable for the level. }\end{array}$ \\
\hline Relations & $\begin{array}{l}\text { Mathematical objects are inter-related. } \\
\text { The different meanings of the objects involved are } \\
\text { identified and articulated. }\end{array}$ \\
\hline
\end{tabular}

The arithmetic approach to the study of proportionality predominates in many of the curricular proposals, innovations and research available (Ben-Chaim, Keret, \& Ilany, 2012; Lamon, 2007; Martínez, Muñoz, Oller, \& Pecharromán, 2015). On the other hand, studies on how proportionality is addressed in textbooks reveal that this mainly follows an arithmetic approach, without reference to its potential functional characterization (Martínez, Muñoz, Oller, \& Ortega, 2017). Consequently, the arithmetic approach to proportionality has been considered when assessing the suitability of the level of language used or the rules and arguments introduced in the didactic sequences. Nevertheless, it should be noted that algebra as such is also covered in the first cycle of Compulsory Secondary Education (CSE), that proportionality can be seen as a precursor to algebraic thinking (Lundberg \& Kilhamn, 2016), and the connections between different concepts promote learning (Novo, Alsina, Marbán, \& Berciano, 2017).

Consequently, we have found it useful in this study to employ the linguistic characteristics of algebrization levels 0,1 and 2, bearing in mind that the subjects these videos are aimed at are second-year CSE students (13-14 years old) in the Spanish education system. That is, natural language, symbolic and numeric language, iconic and gestural language, as well as literal symbols that refer to extensive objects or unknown data (level 0) or are used to refer to recognized intensive objects, linked always to spatial, temporal and contextual information (levels 1 and 2). The use of literal symbols in an exclusively analytical way (without meanings), without reference to contextual information, is characteristic of level 3.

Also assessed favourably are the uses of rules, propositions and arguments that make use of objects with a second degree of generality (sets, classes or types of numbers), of the relational meaning of equality, or that use unknowns as generalized numbers or changing quantities, which can be analytically expressed in the form of $\mathrm{Ax} \pm \mathrm{B}=\mathrm{C}$ (level 2).

Each of these indicators was assessed according to whether their level of suitability was low, average or high, and was assigned a numerical score of 0,1 or 2, respectively. However, given the importance attributed to relations and connections between different objects and meanings in all theoretical frameworks (Novo et al., 2017), these components were quantified with 0,2 or 4 . This 
procedure is in line with similar initiatives that aim to measure the mathematical quality of instruction (Learning Mathematics for Teaching Project, 2011).

The coding of the videos was carried out by the authors during a process comprising three cycles. Initially, each author was responsible for coding a third of the videos. This first cycle resulted in the need to establish more specific compliance criteria, since discrepancies emerged when deciding whether or not some of the indicators were activated. In the second cycle of coding, each author was responsible for a different third of the videos from those analysed in the first cycle. The specific requirement that emerged during this phase was the need to define the algebraic level of certain kinds of solutions, especially when these did not attribute meaning to the mathematics objects used. The fact that a specific indicator exists for the relation between objects (assignation of meanings) led us to consider that the algebraic level of a kind of solution corresponded to its prototypical expression, except in the case of the rule of three, which always appears in a degenerated form in the sample videos. Finally, during the third cycle, each author was responsible for the videos that they had not already coded.

\section{Results}

\section{Type of solution and algebraic levels}

Seven videos of the sample (23\%) present part-whole type solutions; six videos (19\%) show the unitary method; 11 (35\%) missing value; and 10 videos (32\%) cover solutions through equations based on the constant of proportionality. These forms of solution cover algebrization levels 1 and 2. Only two of the videos include more than one type of solution (an aspect that has been taken into account in the calculation of the percentages), making comparisons between them, which is assessed in Relations between mathematical objects. None of the videos include purely diagrammatic solutions or solutions characteristic of algebrization levels 0 or level 3 upwards. Some variations are observed. Thus, of the seven part-whole solutions, one is carried out using percentages, and of the 11 on missing value, eight can be distinguished in which the representation used is the equality of fractions and three which are solved using the classic arrangement of the rule of three. In the resolution based on an equation with an unknown, the constant of proportionality stands at level 2 . Nevertheless, and as shown later, the symbolic treatment typically used in the videos is characteristic of level 3 (without reference to context).

\section{Languages used}

The analysis carried out on the sample has identified the use of different registers and linguistic representations, which are summarized in Table 2.

In the first place, we observe that natural language appears orally in all the videos, while written representation is only used in a third of them (without taking into account the statement of the problem). A similar number of videos also use this kind of representation, but only through abbreviations or isolated words used for labelling. For this reason they have been counted as a different 
Table 2. Linguistic registers and representations.

\begin{tabular}{lcc}
\hline Registers and representations & Videos & $\%$ \\
\hline Natural (Oral) & 31 & $100 \%$ \\
Symbolic (numerical) & 31 & $100 \%$ \\
Symbolic (algebraic) & 20 & $66 \%$ \\
Natural (written) & 11 & $35 \%$ \\
Gestural & 13 & $32 \%$ \\
Natural (written, only labels) & 9 & $29 \%$ \\
Digital effects & 8 & $26 \%$ \\
Tabular & 7 & $23 \%$ \\
Graphic & 6 & $19 \%$ \\
Animation & 1 & $3 \%$ \\
Dramatization & 1 & $3 \%$ \\
\hline
\end{tabular}

category to the previous one. On the other hand, many videos show recordings made by teachers (or a student under the supervision of their teacher) solving a specific problem on the blackboard, in which gestures inevitably appear, whether to point something out or to emphasize spoken discourse, in such a way that they have a clear purpose in the discourse.

Attending to symbolic language, a distinction has been made between the use of symbolic-numerical and/or symbolic-algebraic linguistic objects. A purely arithmetic hypothetical solution would use only the first, whereby as we ascend through the algebrization levels literal symbols would be introduced, as well as other elements that generalize classes of objects.

The use of tables is also common, mainly to show the data of the problem, and is found in a third of the sample. Regarding the graphic register, while different representations are found, the analysis has not observed if they were modelling the complete situation (Figure 1) or if, by contrast, they were signs,

Costo del boleto

Aportación total $\$ 40$

\begin{tabular}{|c|c|c|c|c|c|c|c|}
\hline Ro & Ro & Ro & Ro & Ro & Ro & Ro & Ro \\
\hline Ro & Rò & Ro & Ro & Ro & Ro & Ro & Ro \\
\hline $\mathbf{J u}$ & $\mathbf{J u}$ & Ju & $\mathrm{Ru}$ & $\mathbf{R u}$ & $\mathrm{Ru}$ & $\mathrm{Ru}$ & Ru \\
\hline $\mathbf{J u}$ & $\mathbf{J u}$ & Ju & $\mathbf{R u}$ & $\mathbf{R u}$ & $\mathbf{R u}$ & $\mathrm{Ru}$ & $\mathbf{R u}$ \\
\hline Ju & Ju & Ju & $\mathbf{R u}$ & $\mathrm{Ru}$ & $\mathrm{Ru}$ & $\mathrm{Ru}$ & $\mathbf{R u}$ \\
\hline
\end{tabular}

Figure 1. Example of diagrammatic representation in video 03. 


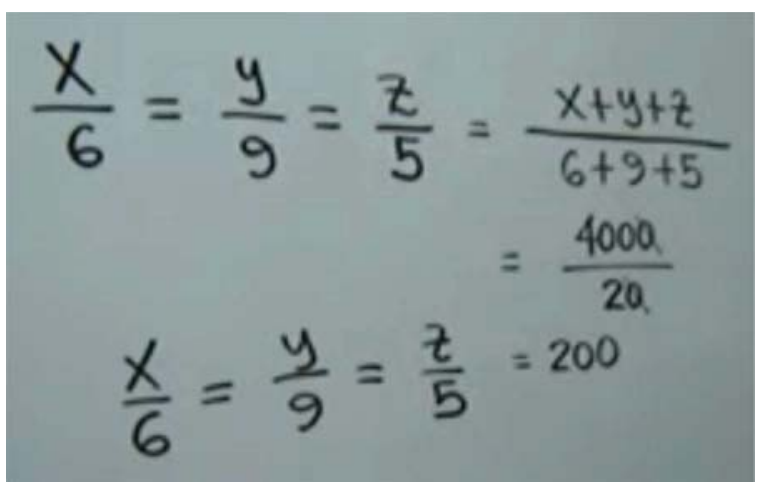

Figure 2. Decontextualized use of symbolic-algebraic register, characteristic of level 3, in video 01 .

drawings and arrows used to organize ideas (Aguilar, Navarro, \& Alcalde, 2003) or to show isolated aspects of the resolution process. Finally, Table 2 also shows data on other registers, such as the use of highlighting effects or movement, which are characteristic of office automation presentations or animations and dramatizations that represent the distribution problem in question.

The videos of the sample which are the most linguistically rich use six or seven registers or different representations and have been considered to be highly suitable, while the poorest in this regard only used three, presenting low levels of suitability.

As mentioned above regarding the suitability of the linguistic registers used, half the videos (16) of the sample follow a process with literal symbols, without making any reference to the context. As a result, these are considered to have a low level of suitability. An example of this can be found in the video capture 01 in Figure 2, in which natural oral language does not provide information on context during the procedure.

\section{Rules (concepts-definition, propositions and procedures)}

A factor that contributes to suitability is that definitions, propositions and procedures are clear and correct. Analysis of the videos of the sample shows that errors and inaccuracies are produced with considerable frequency.

Only one of the videos defines a directly proportional distribution situation correctly, as that in which if a person contributes 'double', they should be allocated 'double' in the distribution, etc. We observed that nine of the videos $(29 \%)$ commit the error of defining this type of situation in additive terms, in the sense that the one who contributes 'the most' in the first place receives 'the most' later:

[Video 13] 'This is proportional distribution, the more you give, the more you get back' 


$$
\begin{aligned}
& \text { A: } 3 \frac{1}{4}=\frac{3}{4} \times(36)= \\
& \text { B: } 5 \cdot \frac{1}{6}=\frac{5}{6} \times 36= \\
& \text { C: } 8 \cdot \frac{1}{9}=\frac{8}{9} \times 36=
\end{aligned}
$$

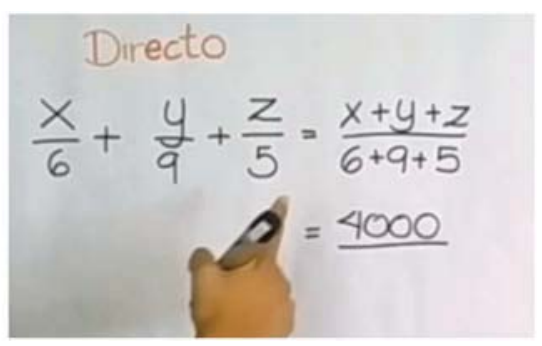

Figure 3. Video 04 (left) and video 15 (right), with errors in symbolic-numerical expression.

The other videos do not establish a definition of directly proportional distribution. On the other hand, this is not the only inaccuracy in language. For example, we find videos based on a situation in which the magnitudes involved and the units of measurement are not identified, in an intra-mathematics context that could be confusing for some students:

[Video 12] 'Split 200 into 3 proportional parts of 2, 3 and 5'

Errors are found in four videos (13\%) in their handling of arithmetic operations and/or algebraic expressions, as shown in the examples provided in Figure 3. Thus, in video 04, three false equalities are written, in an example of a bad use of arithmetic notation. Similarly, video 15 carries out a sum of fractions with a different denominator, directly adding the denominators. Despite this, the final result is correct, since three proportions are extracted from the identity, one for each summand, equalling from the right side to the term of the left in the given expression. Finally, five videos (16\%) include inaccuracies or errors of another kind.

In the overall assessment, the fact that they contained errors or inaccuracies resulted in low suitability levels, whereas the lack of any such errors led to high suitability.

Regarding the degree of suitability of the rules explained in the videos, we can state that all of them correspond to levels 1 and 2. In other words, although it is true that some videos tend to overuse symbolism, the definitions, propositions and rules used do not use elements corresponding to higher levels of algebrization, such as the use of particular functions, canonical expressions and the manipulation of equations with unknowns in both members, etc.

\section{Arguments}

In the first place, we note that various videos lack any argument. That is to say that, within the system of practices observed, there is nothing to justify the choice made or the reasons for following a certain procedure, or to indicate the points that would support it or the need for a definition. However, this has been 
assessed in Relations between mathematical objects. Here we will focus on whether the arguments that appear are clear and correct, and if they are suitable for the level.

In videos in which the solution presented is tested, the argument aimed at verifying it tends to include a condition which is necessary but not sufficient. For example, to argue that if the sum of the parts obtained is equal to the total then the solution is correct, is not accurate. This occurs in nine of the videos $(29 \%)$. Moreover, if three people are involved in the distribution and the last quantity is calculated as the difference between the total and the sum of the first two, the verification does not lead to a valid conclusion, since the sum of the parts will obviously coincide with the total. The same occurs when we test whether the one who contributes the most is finally the one who receives the most, and that the one who contributes the least is the one who receives the least. Once again, this is a necessary condition, but one which does not guarantee having reached the correct solution, as observed in 11 of the videos (35\%), which do not allude to the fact that this is not a sufficient condition.

In the overall assessment, the fact that the arguments contained errors or inaccuracies resulted in low suitability, whereas the lack of any such errors led to high suitability. On the other hand, the analysis of the arguments revealed that all the ones provided are adequate for the level of first cycle of CSE, since they do not use elements characteristic of level 3 of algebrization (particular functions or canonical forms of expression).

\section{Relations between mathematical objects}

In line with proposals of the onto-semiotic approach, objects used in a mathematics teaching-learning sequence can be categorized as situations-problems, languages, propositions, rules (concepts-definition, propositions and procedures) and arguments. These are not isolated entities, and relations are established between them. One way of quantifying the existence of these kinds of relations is to determine if arguments exist that justify each of the rules exposed, if arguments are put forward only in relation to some of them or if no arguments exist to relate them together. In this sense, the analysis reveals that only six videos of the sample (19\%) provide arguments for all of the rules introduced. On the other hand, in 13 videos (42\%) arguments are only provided for some of the propositions and procedures, and in 13 (39\%) no arguments whatsoever are provided.

A specific indicator of suitability regarding the articulation of the different meanings of the objects involved is used. On some occasions linguistic expressions are not even assigned a meaning. For example, the symbol $k$ is sometimes written and used as a constant of proportionality, but without saying what it signifies or represents. Most videos neglect this aspect. In this way, video 14 identifies the meaning of $k$ - 'We're going to call the quantity of money that a person would make in one hour $k$ ' - but, later on, when calculating the value of 
$k$, they do not specify that the number obtained $(k=21.5)$ is euros, dollars or pesos per hour.

The analysis of the sample reveals that only four of the videos (13\%) identify and articulate the different meanings of the objects involved, while 15 videos $(48 \%)$ only identify them sometimes, and in 12 videos $(39 \%)$ the teacher makes no reference to them. The meaning of the literal used as a constant of proportionality (normally, ' $k$ ') is the element which is the least identified in the videos. In this way, certain videos make use of the literals $x, y$ and $z$ to symbolize the unknown quantities in distribution, taking care to specify what it is that $x, y$ and $z$ refer to (video 21). However, later on, the constant of proportionality appears without its meaning being established.

\section{Discussion and conclusions}

Our analysis of the results has led us to identify lacks that appear repeatedly in many of the videos analysed. It is therefore noteworthy that $13 \%$ of the videos present errors in the development of arithmetic or algebraic procedures. Nevertheless, the most common error (29\%) consists of defining a situation of directly proportional distribution as one in which the one who contributes the most is the one who receives the most, instead of using multiplicative terms such as double, triple, etc. This inaccuracy appears again in the arguments used to verify the solution (35\%) and further reinforces the 'illusion of linearity' (De Bock, Verschaffel, \& Janssens, 1998). In this way, students frequently fall into the trap that this illusion of linearity sets, insofar as they try to apply proportional reasoning to situations that do not allow this, both in terms of intra-mathematics as well as in other fields of knowledge.

Four different types of solutions have been found which correspond to levels 1 and 2 of algebrization, and the treatment of one of level 2 included elements belonging to level 3 . The mathematical objects that emerge from the systems of practice articulated in each type of solution are different, as are the relations established between them. In fact, as shown, some videos do not establish relations between the different objects. This may interfere with the process of negotiating meanings upon which teachers set their teaching sequences (Planas, 2005). For example, some studies explore the disparity shown by mathematics teachers in the criteria used to correct exams (Arnal-Bailera, Muñoz-Escolano, \& Oller-Marcén, 2016). What for one teacher is a simple procedural error that counts little in terms of the marks awarded, for others is regarded as something that should be penalized. In this way, if a student has revised using this kind of resource and is unable to distinguish their quality and the way in which they present mathematics content, a semiotic conflict may emerge in the form of a disparity of meanings attributed to the mathematics objects involved.

Quantifying the degree of epistemic suitability of each video in a concrete manner is complex. Reducing it to a simple number of all the dimensions covered by the epistemic facet most certainly leads to a loss of information. Aware of this limitation, in this study we have calculated the degree of suitability 
in a similar way to other authors (Learning Mathematics for Teaching Project, 2011). In general, the values shown in Table 3 show low epistemic suitability, in line with the results of similar studies for other fields of knowledge, such as experimental and social sciences (Bortoliero \& León, 2017; Tan, 2013).

According to the coding scheme described, the maximum score for epistemic suitability that a video can obtain is 20 points. Table 3 shows that only eight videos $(26 \%)$ obtain high scores (16 or more), while 19 (61\%) show low or very low suitability, equal to or lower than eight points. It is worth noting that epistemic suitability is only one of the six facets into which the suitability of a teaching-learning sequence is broken down. This means that other aspects have been taken into account, such as affective (interest, affinity), mediational (aesthetics, duration), cognitive and ecological. The videos have also been analysed in an isolated manner, without considering the hypothetical teaching unit in which they could be contextualized. This means that some videos which are epistemically poor could be suitable, in a certain way, if their duration is brief (mediational suitability), or if they describe a procedure whose meanings are explained in another moment (cognitive and ecological suitability). In any event, it is worth noting that, on principle (Breda, Font, \& Pino-Fan, 2018), this study clearly shows that the criteria of suitability are not dichotomous or binary but gradual.

Regarding the use of didactic suitability, as a theoretical-methodological construct applied a posteriori, it is shown to be a useful and operative tool for this kind of study, on similar lines to those of Santos (2018).

The most direct conclusion of our study is in line with that of other authors, such as Jones and Cuthrell (2011), who call for the need to critically select videos with educational value. From the perspective of the specific didactics of mathematics, it is essential that teachers themselves are the ones who recommend the most suitable videos for their students (Ruiz-Reyes et al., 2017; Santos, 2018), for different reasons:

- Some videos show procedures which are formally incorrect.

- Not all the videos indicate the educational level at which they are aimed.

- The meanings discussed in the video may not be consistent with what they are covering in class.

- The greater popularity of a video is not indicative of its suitability.

At the same time, it is also true to say that actions should be established to develop teachers' capacity to analyse these videos as well as any other resources (Giacomone, Godino, \& Beltrán-Pellicer, 2018). 


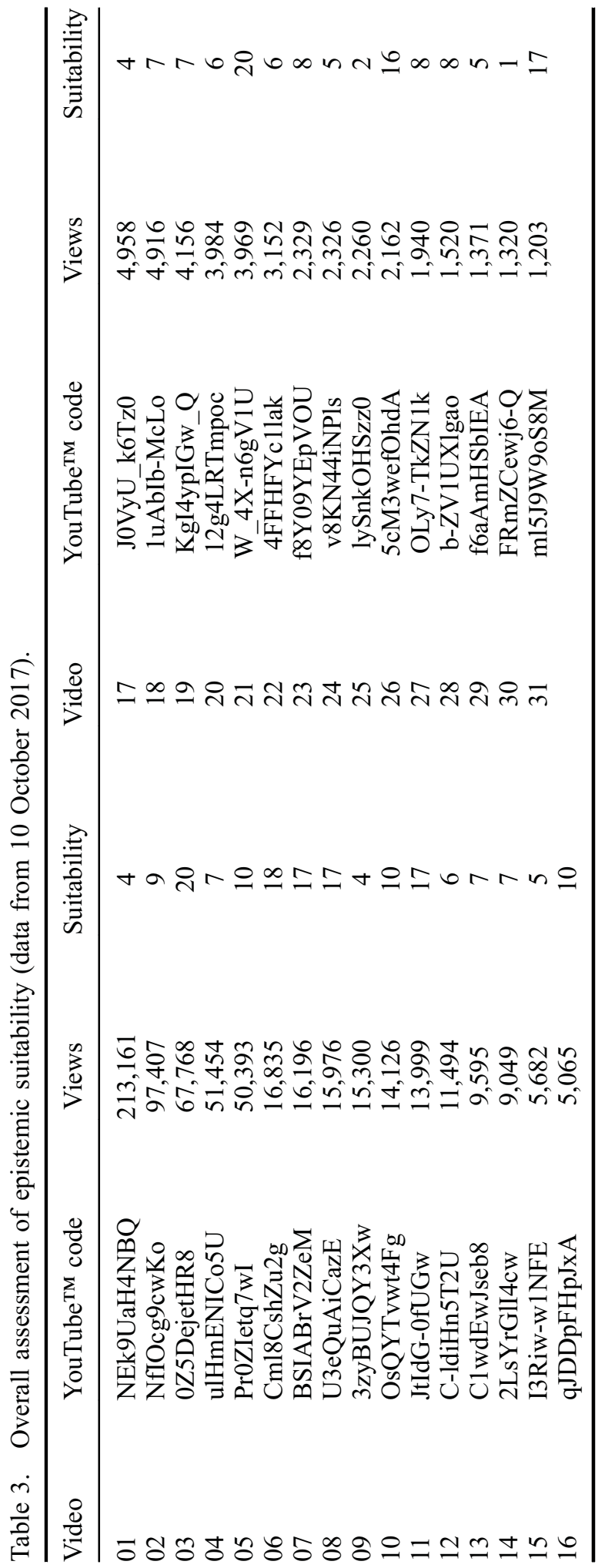




\section{Los vídeos educativos en línea desde las didácticas específicas: el caso de las matemáticas}

El fenómeno de los vídeos educativos alojados en plataformas en línea no es nuevo. El alumnado de secundaria y, en menor medida, el de primaria, dedica gran parte de su tiempo de ocio a las redes sociales, entre las cuales se encuentran servicios y aplicaciones donde se comparten vídeos. De esta forma, es natural que utilicen estas producciones para ayudarse en sus estudios y diversos autores destacan que los vídeos de YouTube ${ }^{\mathrm{TM}}$ son ampliamente aceptados por la comunidad estudiantil como medio para el aprendizaje de las matemáticas (Ramírez, 2010). Por otro lado, este tipo de vídeos constituyen un recurso muy utilizado en ciertas propuestas pedagógicas, como en el 'flipped learning' (Davies, Dean, \& Ball, 2013).

La disponibilidad de recursos en la red que apoyan el aprendizaje de las matemáticas genera que muchos estudiantes, antes de consultar a su profesor, visiten estos sitios online. Esto plantea preguntas sobre cómo se organizan los recursos para facilitar el acceso y cómo se diseñan pedagógicamente para fomentar la comprensión conceptual (Borba et al., 2016, p. 606). Es necesario, por tanto, que las didácticas específicas indaguen sobre el grado de adecuación de estas propuestas de enseñanza-aprendizaje, asegurando de esta forma que la tecnología esté alineada con los objetivos de aprendizaje (Turney, Robinson, Lee, \& Soutar, 2009, p. 80).

En este sentido, algunas investigaciones describen el diseño y la implementación de tutoriales. Así, Márquez (2002) se propone elaborar tutoriales multimedia para facilitar el aprendizaje de conceptos estadísticos. Si bien sostiene la importancia de un diseño del vídeo rico en contenido matemático, no evalúa la idoneidad epistémica del recurso, sino que se limita a señalar los efectos positivos sobre aspectos de motivación y actitud en los usuarios (faceta afectiva). Arguedas y Herrera (2016) implementan una encuesta con un grupo de estudiantes para valorar tutoriales de un canal de YouTube ${ }^{\mathrm{TM}}$, centrándose en aspectos audiovisuales, sobre el contenido y sobre la instrucción. Respecto al contenido, aunque los resultados aluden favorablemente a la variedad de problemas representativos, conexiones entre los tópicos enseñados y uso de distintas estrategias, los estudiantes proponen que para mejorar el material sería adecuado incluir una buena cantidad de ejercicios por cada tema.

Si bien varias investigaciones han contribuido al estudio de la utilización de vídeos educativos, los resultados obtenidos respecto al tipo de resolución de problemas y contenido matemático exhibido son escasos, aunque están comenzando a publicarse trabajos en esta línea (Ruiz-Reyes, Contreras, Arteaga, \& Oviedo, 2017; 
Santos, 2018). Teniendo en cuenta esta problemática, en este estudio se describe y se interpreta la faceta epistémica de videos educativos en línea previamente seleccionados, teniendo como objetivo general valorar el grado de adecuación epistémica de los vídeos más vistos por los usuarios en YouTube ${ }^{\mathrm{TM}}$.

\section{Idoneidad didáctica}

Para el desarrollo de esta investigación se ha seguido una metodología cualitativa, de carácter interpretativo-valorativo, apoyada por herramientas teóricometodológicas del enfoque ontológico-semiótico del conocimiento y la instrucción matemáticos (EOS) (Godino, Batanero, \& Font, 2007). Desde este marco de investigación en didáctica de la matemática se define la idoneidad didáctica como el grado en que un proceso de instrucción reúne ciertas características que permiten calificarlo como adecuado para la adaptación entre los significados personales obtenidos por los alumnos (aprendizaje) y los significados institucionales, ya sean pretendidos o implementados (enseñanza), considerando la influencia del entorno (Godino, 2013). Esto supone la articulación coherente y sistémica de seis facetas (Godino et al., 2007, p. 133): epistémica, ecológica, cognitiva, afectiva, interaccional y mediacional. Para cada una de ellas, Godino (2013) propone un sistema de criterios generales para que sean consideradas de calidad. Estos criterios de idoneidad didáctica son potentes herramientas para organizar la reflexión y evaluación de un proceso de instrucción (Breda, Pino-Fan, \& Font, 2017, p. 1893), por lo que, a priori, resulta conveniente utilizarlos para analizar y valorar los vídeos de la muestra considerada. De acuerdo con este último aspecto, Santos (2018) propone un modelo para valorar vídeos educativos de matemáticas disponibles en Internet considerando tres componentes: la noción de idoneidad didáctica establecida en el EOS, la lógica difusa para considerar la evaluación mediante una opinión de las comunidades de interés y métodos multicriterio (TOPSIS), para ordenar los datos obtenidos y tomar decisiones a partir de ellos.

\section{Faceta epistémica}

El foco de este trabajo está en la faceta epistémica de vídeos educativos en línea, la cual refiere a la enseñanza de una 'buena matemática' (Breda et al., 2017, p. 1898). La idoneidad epistémica se considera mayor en la medida que los contenidos pretendidos o implementados representan bien a los contenidos de referencia. Así, para que el proceso de enseñanza observado sea considerado de calidad, se debe tener en cuenta dos criterios fundamentales (Godino, 2013):

- La presencia de diversos significados del contenido correspondiente y su interconexión.

- El reconocimiento de la diversidad de objetos primarios y procesos implicados para los diversos significados. 
En el marco del EOS las situaciones-problemas tienen un rol central, de modo que los objetos matemáticos participan y emergen de los sistemas de prácticas matemáticas (acciones realizadas por un sujeto para resolver un problema). Bajo esta perspectiva ontosemiótica, la actividad matemática se puede describir y analizar a partir de una tipología explícita de objetos, los cuales interactúan entre sí formando una red de conocimiento. Según su naturaleza y función, estas entidades primarias se clasifican en las siguientes categorías (Godino et al., 2007):

- Lenguajes (en sus diversos registros y representaciones, natural, gestual, simbólico, gráfico, etc.).

- Situaciones-problemas (aplicaciones intra y extra-matemáticas, ejercicios, problemas).

- Reglas:

- Conceptos-definición (conceptos introducidos mediante definiciones o descripciones, proporcionalidad, función, etc.).

- Proposiciones (enunciados sobre conceptos-definición).

- Procedimientos (algoritmos, operaciones, técnicas de cálculo).

- Argumentos (enunciados usados para validar o explicar las proposiciones y procedimientos).

La aplicación de la idoneidad didáctica requiere delimitar el objeto de estudio para lograr análisis específicos más ricos. En este caso, el foco de atención apunta a un contenido muy específico y que aparece en un momento concreto del currículo: los repartos directamente proporcionales. Este tipo de situación-problema aparece en el primer ciclo de educación secundaria en España, dentro del bloque dedicado a 'Números y álgebra' de la LOMCE, y las concreciones curriculares autonómicas lo incluyen en $2^{\circ}$ ESO (13-14 años). Además, la proporcionalidad es un tema recurrente en los canales educativos de YouTube ${ }^{\mathrm{TM}}$.

Centrar la atención sobre los repartos directamente proporcionales permite además hacer uso del modelo de razonamiento algebraico escolar propuesto desde el EOS para analizar ciertos componentes de la idoneidad epistémica. El modelo en cuestión distingue distintos niveles de algebrización de las prácticas matemáticas que se realizan al resolver tareas propias de Educación Primaria y Secundaria (Godino, Aké, Gonzato, \& Wilhelmi, 2014; Godino et al., 2015). Dichos niveles se definen teniendo en cuenta los tipos de representaciones usadas, los procesos de generalización implicados y el cálculo analítico que se pone en juego en la actividad matemática correspondiente, resultando los tres primeros niveles que son suficientes para nuestro trabajo. 


\section{Materiales y método}

\section{Muestra}

Entre las plataformas de Internet que alojan vídeos de libre acceso, centramos la atención en YouTube ${ }^{\mathrm{TM}}$ por ser 'líder de vídeos en Internet en un gran número de países del mundo, entre ellos, en España' (Camacho \& Alonso, 2010, p. 159). Una búsqueda por vídeos en YouTube ${ }^{\mathrm{TM}}$ con las palabras clave 'repartos proporcionales' devuelve 1,370 resultados. Con el fin de considerar los videos más populares en la red, se han seleccionado solamente aquellos con más de 1,000 visitas. De esta forma, se reduce el conjunto a 60 vídeos. De ellos, aproximadamente la mitad tratan exclusivamente repartos inversamente proporcionales o compuestos, de manera que la muestra final de estudio queda determinada por 31 vídeos, que se listan en la Tabla 3 de la sección Discusión y conclusiones.

\section{Método}

\section{Significados de referencia}

Trabajos realizados en el marco del EOS (Burgos, Giacomone, Beltrán-Pellicer, \& Godino, 2017) han profundizado en la interpretación de los significados del objeto proporcionalidad en términos de los sistemas de prácticas que se realizan para resolver cierto tipo de situaciones problemas que pueden adaptarse fácilmente al caso de los repartos directamente proporcionales:

- Soluciones de nivel 0: significado aritmético. Se caracteriza por la aplicación de procedimientos de cálculo aritméticos (multiplicación, división) y la ausencia de objetos y procesos algebraicos.

- Soluciones de nivel 1: significado proto-algebraico. Se hace uso de las razones y proporciones, como objetos de un segundo grado de generalización. Esta generalidad de los objetos intensivos se reconoce mediante un lenguaje natural, numérico o icónico, distinto al simbólicoliteral, y se aplican relaciones y propiedades de las operaciones. Ejemplos de este tipo de razonamiento son la solución 'parte-todo', donde se hace uso de la fracción como operador; la reducción a la unidad, donde se halla la razón unitaria y ciertos tipos de soluciones diagramáticas.

- Soluciones de nivel 2: significado proto-algebraico. Se plantea la situación como un problema de valor perdido que involucra una incógnita y el planteamiento de una ecuación que se resuelve, idealmente, mediante el método de igualdad de razones. En ocasiones, este tipo de solución se desarrolla como 'regla de tres', aunque frecuentemente aparece de forma degenerada, esto es, sin hacer referencia a los significados de los objetos que intervienen.

- Soluciones de nivel 3: significado algebraico. Se emplean símbolos de manera analítica, sin aludir al contexto y se opera con las expresiones para obtener formas simplificadas. 
Tabla 1. Esquema de codificación según los componentes de la idoneidad epistémica.

\begin{tabular}{ll}
\hline & \multicolumn{1}{c}{ Registros y representaciones. } \\
\cline { 2 - 2 } Lenguajes & Adecuación del nivel del lenguaje empleado. \\
\hline Reglas (definiciones, proposiciones y & $\begin{array}{l}\text { Claridad y corrección. } \\
\text { procedimientos) }\end{array}$ \\
Argumentos (explicaciones, & Las reglas son adecuadas para el nivel. \\
comprobaciones, demostraciones) & Los argumentos son adecuados para el nivel. \\
Relaciones & Los objetos matemáticos se relacionan entre sí. \\
& Se identifican y articulan los diversos \\
& significados de los objetos que intervienen. \\
\hline
\end{tabular}

\section{Procedimiento de codificación y de valoración}

Se codificó cada uno de los vídeos en función de los indicadores propuestos para la idoneidad epistémica por Godino (2013), descartando aquellos que carecen de sentido en este trabajo por tratarse de un medio unidireccional y sin estar enmarcado a priori en una secuencia didáctica. Por ejemplo, no tiene sentido valorar que la muestra de situaciones-problema sea variada y representativa, pues los vídeos educativos únicamente presentan, normalmente, una situación. Por lo tanto, los indicadores considerados fueron los que se exponen en la Tabla 1.

El enfoque aritmético propio del estudio de la proporcionalidad es el que predomina en muchas de las propuestas curriculares, innovaciones e investigaciones (Ben-Chaim, Keret, \& Ilany, 2012; Lamon, 2007; Martínez, Muñoz, Oller, \& Pecharromán, 2015). Por otro lado, los estudios sobre el tratamiento de la proporcionalidad en los libros de texto revelan que es fundamentalmente aritmético, sin hacer referencia a la posible caracterización funcional (Martínez, Muñoz, Oller, \& Ortega, 2017). Consecuentemente, se ha considerado esta aproximación aritmética a la proporcionalidad cuando se ha valorado la adecuación del nivel del lenguaje empleado o de las reglas y argumentos introducidos en la secuencia didáctica. Sin embargo, hay que tener en cuenta que el álgebra como tal es un contenido que también se aborda durante el primer ciclo de ESO, que la proporcionalidad puede verse como un precursor del pensamiento algebraico (Lundberg \& Kilhamn, 2016) y que las conexiones entre los diferentes conceptos favorecen el aprendizaje (Novo, Alsina, Marbán, \& Berciano, 2017).

Por lo tanto, en este trabajo se ha considerado adecuada la utilización de elementos lingüísticos propios de los niveles de algebrización 0,1 y 2 , teniendo en mente que el sujeto al que van dirigidos los vídeos es un hipotético estudiante de $2^{\circ}$ de ESO (13-14 años) en el marco curricular español. Es decir, lenguaje natural, simbólico-numérico, icónico, gestual, así como símbolos literales que se refieran a objetos extensivos o datos desconocidos (nivel 0) o empleados para referir a objetos intensivos reconocidos, aunque siempre ligados a la información espacial, temporal y contextual (niveles 1 y 2). El empleo de símbolos literales 
de forma meramente analítica (sin significados), sin referir a información contextual es propio del nivel 3 .

Igualmente, se ha valorado como adecuado el empleo de reglas, proposiciones y argumentos que hacen uso de objetos con un segundo grado de generalidad (conjuntos, clases o tipos de números), del significado relacional de la igualdad y que emplean incógnitas a modo de números generalizados o cantidades cambiantes, cuya expresión analítica puede llegar a ser de la forma $\mathrm{Ax} \pm \mathrm{B}=\mathrm{C}$ (nivel 2).

Cada uno de estos indicadores se valoró según que su contribución a la idoneidad fuera baja, media o alta, asignando los valores numéricos 0,1 o 2 , respectivamente. Sin embargo, dada la importancia que se atribuye en todos los marcos teóricos a las relaciones y conexiones entre los diferentes objetos y significados (Novo et al., 2017), estos componentes se cuantificarán con 0,2 o 4 . Este procedimiento es acorde con iniciativas similares que tratan de medir la calidad matemática de la instrucción (Learning Mathematics for Teaching Project, 2011).

La codificación de los vídeos fue realizada por los autores a lo largo de un proceso de tres ciclos. Inicialmente, cada uno se encargó de codificar un tercio de los vídeos. Este primer ciclo llevó a la necesidad de establecer criterios más específicos de cumplimiento, ya que surgieron discrepancias al calificar la activación o no de alguno de los indicadores. En el segundo ciclo de codificación, cada autor se encargó de un tercio diferente de los vídeos que ya analizó en el primero. Durante esta fase, simplemente surgió la necesidad de precisar el nivel algebraico de ciertos tipos de soluciones, especialmente cuando estas no atribuían significado alguno a los objetos matemáticos implicados. Al existir un indicador específico para la relación entre objetos (asignación de significados), consideramos que el nivel algebraico de un tipo de solución era el correspondiente a su expresión prototípica, salvo en el caso de la regla de tres, que en la muestra de vídeos siempre aparece de forma degenerada. Por último, en el tercer ciclo cada autor se encargó del resto de vídeos que no había codificado todavía.

\section{Resultados}

\section{Tipo de solución y niveles algebraicos}

En siete vídeos de la muestra (23\%), se plantean soluciones del tipo parte-todo; en seis vídeos (19\%), reducción a la unidad; en 11 vídeos (35\%), valor faltante; y en 10 vídeos (32\%), se resuelve mediante ecuaciones basadas en la constante de proporcionalidad. Estas formas de resolución recorren los niveles de algebrización 1 y 2 . Únicamente dos de los vídeos incluyen más de un tipo de solución (aspecto que se ha tenido en cuenta en el cálculo de los porcentajes), relacionándolas entre sí, aspecto que será valorado en el apartado de Relaciones entre los objetos matemáticos. Ninguno de los vídeos incluye una solución puramente diagramática ni soluciones propias de niveles de algebrización 0 o de nivel 3 y superiores. Sí que se observan algunas variantes. Así, de las siete soluciones parte-todo, una se realiza mediante el empleo de porcentajes y entre las 11 de valor faltante, se pueden distinguir ocho en los que la representación 
utilizada es la igualdad de fracciones y tres que se resuelven mediante la disposición típica de la regla de tres. En la resolución basada en una ecuación con una incógnita, la constante de proporcionalidad se ubica en el nivel 2. Sin embargo, como se muestra más adelante, el tratamiento simbólico que se suele hacer en los vídeos sea propio del nivel 3 (sin aludir al contexto).

\section{Lenguajes empleados}

En el análisis llevado a cabo sobre la muestra se ha identificado el empleo de diferentes registros y representaciones lingüísticas, las cuales se sintetizan en la Tabla 2.

Se observa en primer lugar que el lenguaje natural aparece de forma oral en todos los vídeos, mientras que su representación escrita solamente se usa en una tercera parte de ellos (sin tener en cuenta el enunciado del problema). Un número similar de vídeos utilizan también esta representación, pero únicamente a través de abreviaturas o palabras aisladas a modo de etiqueta. Por esta razón, se han contabilizado como una categoría diferente a la anterior. Por otro lado, muchos de los vídeos consisten en una grabación de un profesor (o un estudiante bajo la supervisión de un profesor) resolviendo un problema determinado en la pizarra, por lo que aparecen gestos de forma irremediable, bien para señalar algo o para enfatizar su discurso hablado, de forma que tienen una finalidad en el discurso.

Atendiendo al uso del lenguaje simbólico se ha distinguido entre la utilización de objetos lingüísticos simbólico-numéricos y/o simbólico-algebraicos. Una hipotética solución puramente aritmética haría uso exclusivo de los primeros, mientras que conforme ascendemos en los niveles de algebrización, se introducirían símbolos literales y otros elementos que generalizan clases de objetos.

El uso de tablas, principalmente para disponer los datos del enunciado también es bastante común, detectándose en un tercio de la muestra. En cuanto al registro gráfico, si bien es cierto que hay una diversidad de representaciones, no se ha distinguido en el recuento si se estaba modelando la situación completa

Tabla 2. Registros y representaciones lingüísticas.

\begin{tabular}{lcc}
\hline Registros y representaciones & Vídeos & $\%$ \\
\hline Natural (oral) & 31 & $100 \%$ \\
Simbólico (numérico) & 31 & $100 \%$ \\
Simbólico (algebraico) & 20 & $66 \%$ \\
Natural (escrito) & 11 & $35 \%$ \\
Gestual & 13 & $32 \%$ \\
Natural (escrito, solo etiquetas) & 9 & $29 \%$ \\
Efectos digitales & 8 & $26 \%$ \\
Tabular & 7 & $23 \%$ \\
Gráfico & 6 & $19 \%$ \\
Animación & 1 & $3 \%$ \\
Dramatización & 1 & $3 \%$ \\
\hline
\end{tabular}


Costo del boleto

Aportación total \$40

\begin{tabular}{|c|c|c|c|c|c|c|c|}
\hline Ro & Ro & Ro & Ro & Ro & Ro & Ro & Ro \\
\hline Ro & Ro & Ro & Ro & Ro & Ro & Ro & Ro \\
\hline Ju & Ju & Ju & Ru & Ru & Ru & Ru & Ru \\
\hline Ju & Ju & Ju & Ru & Ru & Ru & Ru & Ru \\
\hline Ju & Ju & Ju & Ru & Ru & Ru & Ru & Ru \\
\hline
\end{tabular}

Figura 1. Ejemplo de representación diagramática en el vídeo 03.

(Figura 1) o si, por el contrario, se trataba de signos, dibujos y flechas para organizar el razonamiento (Aguilar, Navarro, \& Alcalde, 2003) o para mostrar aspectos aislados del proceso de resolución. Finalmente, la Tabla 2 también recoge otros registros, como el empleo de efectos de resaltado o movimiento, propio de presentaciones ofimáticas, o animaciones y dramatizaciones que representan la situación de reparto del problema en cuestión.

Los vídeos de la muestra con mayor riqueza lingüística hacen uso de seis o siete registros o representaciones diferentes y se han valorado con idoneidad alta, mientras que los más pobres en este sentido únicamente emplean tres de ellas, presentando una idoneidad baja.

Según lo comentado para la adecuación de los registros lingüísticos empleados, en la mitad de los vídeos (16) de la muestra se realiza un tratamiento con símbolos literales sin hacer alusión al contexto, que serán valorados con una idoneidad baja. Sirva como ejemplo la captura del vídeo 01 de la Figura 2, donde

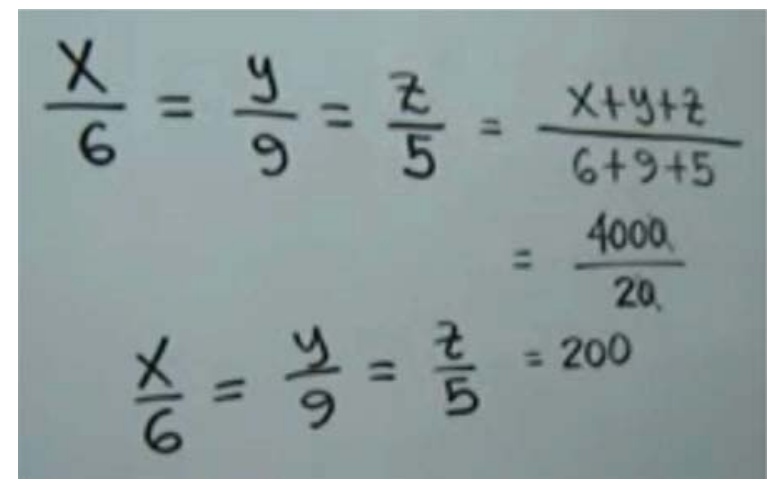

Figura 2. Uso descontextualizado del registro simbólico-algebraico propio de nivel 3 en el vídeo 01 . 
el lenguaje natural oral no añade información relativa al contexto durante el procedimiento.

\section{Reglas (conceptos-definición, proposiciones y procedimientos)}

Un factor que contribuye a la idoneidad es que las definiciones, proposiciones y procedimientos sean elementos claros y correctos. El análisis de los vídeos de la muestra revela que se producen errores e imprecisiones con una frecuencia significativa.

Únicamente uno de los vídeos define una situación de reparto directamente proporcional en términos correctos; como aquella en la que, si una persona aporta el 'doble', le corresponde el 'doble' en el reparto, etc. Se ha encontrado que nueve de los vídeos (29\%) incurren en el error de definir este tipo de situación en términos aditivos, como aquella en la que el que 'más' aportó inicialmente, 'más' recibe:

[Vídeo 13] 'Eso es reparto proporcional, entre que a más cooperes, mayor cantidad te tocará'

El resto de los vídeos no establecen la definición de reparto directamente proporcional. Por otro lado, no es la única imprecisión en el lenguaje. Por ejemplo, hay vídeos que parten de una situación en las que no se identifican las magnitudes que intervienen ni sus unidades de medida, en un contexto intra-matemático que puede resultar confuso para algunos alumnos:

[Vídeo 12] 'Repartir 200 en 3 partes proporcionales a 2, 3 y 5'

En cuatro vídeos (13\%) se identifican errores en el tratamiento de las operaciones aritméticas y/o de las expresiones algebraicas, como se muestra en los ejemplos de la Figura 3. Así, en el vídeo 04 se escriben tres igualdades que son falsas, lo que constituye un mal uso de la notación aritmética. De igual forma, en el vídeo $15 \mathrm{se}$ realiza una suma de fracciones con distinto denominador, sumando los denominadores directamente. No obstante, el resultado final es correcto, porque de la identidad se extraen tres proporciones, una por cada sumando de la derecha igualado al término de

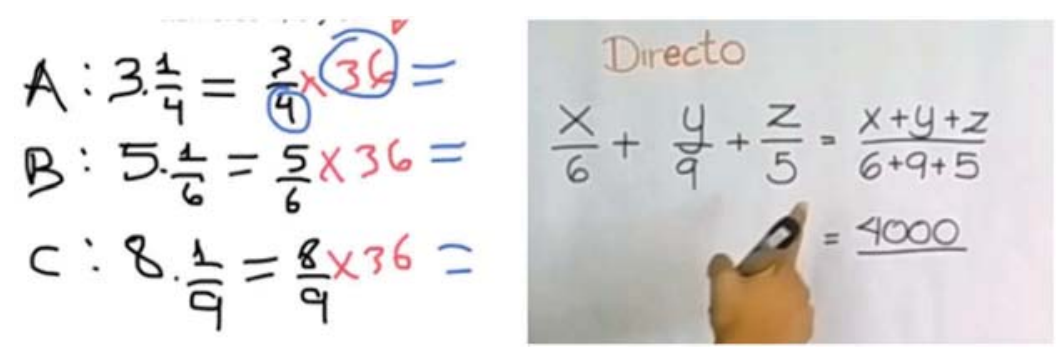

Figura 3. Vídeo 04 (izquierda) y vídeo 15 (derecha), con errores en la expresión simbólico-numérica. 
la izquierda en la expresión dada. Finalmente, en cinco de los vídeos (16\%) se observan imprecisiones o errores de otros tipos.

En la valoración global, se ha valorado como baja idoneidad el hecho de que contuvieran errores e imprecisiones, y como alta si no se producían tales errores.

Respecto al grado de adecuación de las reglas explicitadas en los vídeos, puede decirse que todas se corresponden con las propias de los niveles 1 y 2 . Es decir, aunque es cierto que en algunos vídeos se tiende a abusar del simbolismo, las definiciones, proposiciones y reglas empleadas no hacen uso de elementos de niveles de algebrización superiores, como empleo de funciones particulares, expresiones canónicas y manipulación de ecuaciones con incógnitas en ambos miembros, etc.

\section{Argumentos}

En primer lugar, se aprecia que varios vídeos carecen de argumentos. Esto es, dentro del sistema de prácticas que se observa, no hay nada que justifique la elección o la razón de ser de un procedimiento, o que indique los puntos de apoyo y la necesidad de una definición. Sin embargo, esto es algo que se valorará en Relaciones entre los objetos matemáticos. Aquí nos centraremos en si los argumentos que aparecen son claros y correctos, y si son adecuados para el nivel.

En aquellos vídeos en los que sí se realiza una comprobación de la solución, el argumento destinado a verificarla suele incluir una condición necesaria, pero no suficiente. En concreto, argumentar que, si la suma de las partes obtenidas es igual al total, entonces la solución es correcta, no es preciso. Esto ocurre en nueve de los vídeos (29\%). Además, por ejemplo, si participan tres personas en el reparto y la última cantidad se calcula como la diferencia entre el total y la suma de las dos primeras, la comprobación no conduce a ninguna conclusión válida, pues obviamente la suma de las partes coincidirá con el total. Lo mismo ocurre cuando comprobamos que, efectivamente, el que más aportó es finalmente el que más recibe y que el que menos aportó es el que menos recibe. Vuelve a ser una condición necesaria, pero que no asegura haber alcanzado la solución correcta, y es algo que se observa en 11 de los vídeos $(35 \%)$, que no aluden a que no se trata de una condición suficiente.

En la valoración final, se ha considerado de baja idoneidad el hecho de que los argumentos contuvieran errores e imprecisiones, y como alta si estaban libres de ellos. Por otro lado, el análisis de los argumentos revela que todos los que se proporcionan son adecuados al nivel de primer ciclo de ESO, pues no ponen en juego elementos propios de nivel 3 de algebrización (funciones particulares o formas canónicas de expresión).

\section{Relaciones entre los objetos matemáticos}

En consonancia con los presupuestos del enfoque ontosemiótico, los objetos que conforman una secuencia de enseñanza-aprendizaje de las matemáticas pueden catalogarse como situaciones-problema, lenguajes, proposiciones, reglas (conceptosdefinición, proposiciones y procedimientos) y argumentos. No se trata de entidades aisladas, sino que se establecen relaciones entre ellas. Una manera de cuantificar la 
existencia de este tipo de relaciones es determinando si existen argumentos que justifiquen cada una de las reglas expuestas, si solamente se argumenta sobre alguna de ellas o, incluso, si no existen argumentos que las relacionen. En este sentido, el análisis revela que únicamente seis vídeos de la muestra (19\%) proporcionan argumentos para todas y cada una de las reglas que introducen. Por otro lado, en 13 vídeos (42\%) solamente aparecen argumentos para algunas de las proposiciones y procedimientos y, finalmente, 12 vídeos (39\%) no argumentan en absoluto.

Por otro lado, hay un indicador de idoneidad específico sobre la articulación de los diversos significados de los objetos que intervienen. Hay ocasiones en las que ni siquiera se asigna un significado a una expresión lingüística. Por ejemplo, a veces se escribe y utiliza el símbolo $k$ como constante de proporcionalidad, pero sin decir qué significa o qué representa. La mayoría de los vídeos descuidan este aspecto. Así, el vídeo 14 identifica el significado de $k$ : 'Vamos a llamar $k$ a la cantidad de dinero que tendría una persona en una hora', pero más adelante cuando calcula el valor de $k$, no se especifica que ese número obtenido $(k=21.5)$ son euros, dólares o pesos por hora.

El análisis de la muestra revela que únicamente cuatro de los vídeos (13\%) identifican y articulan los diversos significados de los objetos que intervienen; mientras que en 15 vídeos (48\%) solamente se identifican a veces; y en 12 vídeos (39\%), el profesor no lo hace nunca. Realmente, el significado del literal empleado como constante de proporcionalidad (normalmente, ' $k$ ') es el que menos se identifica en los vídeos. De esta forma, ciertos vídeos hacen uso de los literales $x, y$ o $z$, para simbolizar las cantidades desconocidas en el reparto y que se cuidan de especificar a qué se refieren con $x, y$ o $z$ (vídeo 21), pero posteriormente aparece la constante de proporcionalidad y no se establece su significado.

\section{Discusión y conclusiones}

El análisis de los resultados permite identificar carencias que aparecen de forma recurrente en muchos de los vídeos analizados. Así, es llamativo que un 13\% de los vídeos presente errores en el desarrollo de los procedimientos aritméticos y/o algebraicos. Sin embargo, el error más habitual (29\%) consiste en definir una situación de reparto directamente proporcional como aquella en la que el que más aportó es el que más recibe, en lugar de emplear términos multiplicativos, como doble, triple, etc. Esta imprecisión vuelve a aparecer en los argumentos que se emplean para comprobar la solución (35\%) y contribuye a reforzar la 'ilusión de linealidad' (De Bock, Verschaffel, \& Janssens, 1998). De esta manera, es frecuente que los estudiantes caigan más adelante en el obstáculo que supone esta ilusión de linealidad, al intentar aplicar un razonamiento proporcional en situaciones que no lo admiten, tanto intramatemáticas como de otros campos del saber.

Se han encontrado soluciones de cuatro tipos esencialmente diferentes, correspondientes a los niveles de algebrización 1 y 2 y el tratamiento de alguna de nivel 2 incluía elementos propios de nivel 3. Los objetos matemáticos que emergen de los sistemas de prácticas que se articulan en cada tipo de solución son diferentes, así como las relaciones que se establecen entre ellos. De hecho, como se ha mostrado, algunos vídeos no llegan a relacionar los diversos objetos. 
Todo esto puede interferir con el proceso de negociación de significados sobre el que el docente configura su secuencia didáctica (Planas, 2005). Por ejemplo, algunos estudios indagan en la disparidad que muestran los docentes de matemáticas en los criterios de corrección de los exámenes (Arnal-Bailera, Muñoz-Escolano, \& Oller-Marcén, 2016). Lo que para un profesor es un simple fallo procedimental que influye poco en la calificación, para otro es algo que debe penalizarse más. De esta forma, si un alumno se ha preparado la materia a través de este recurso y no es competente para discriminar ni la calidad de los mismos ni la forma de presentar el contenido matemático, quizá se produzca un conflicto semiótico, esto es, una disparidad de significados atribuidos a los objetos matemáticos implicados.

Cuantificar de forma concreta el grado de idoneidad epistémica de cada vídeo es complejo. La reducción a un simple número de todas las dimensiones que abarca la faceta epistémica conlleva, sin duda, una pérdida de información. Siendo conscientes de esta limitación, en este trabajo se ha calculado el grado de idoneidad de forma similar a lo realizado por otros autores (Learning Mathematics for Teaching Project, 2011). En general, los valores mostrados en la Tabla 3 revelan una baja idoneidad epistémica, lo cual concuerda con resultados de estudios similares para otros campos del conocimiento, como las ciencias experimentales y sociales (Bortoliero \& León, 2017; Tan, 2013).

Según el esquema de codificación descrito, la puntuación máxima que puede alcanzar la idoneidad epistémica de un vídeo es de 20 puntos. La Tabla 3 revela que únicamente ocho vídeos (26\%) alcanzan una valoración alta (16 o más), mientras que 19 vídeos (61\%) muestran una idoneidad baja o muy baja, igual o inferior a ocho puntos. Conviene observar que la idoneidad epistémica es

Tabla 3. Valoración global de la idoneidad epistémica (datos a 10 de octubre de 2017).

\begin{tabular}{|c|c|c|c|c|c|c|c|}
\hline Vídeo & $\begin{array}{c}\text { Código } \\
\text { YouTube }^{\mathrm{TM}}\end{array}$ & Vistas & Idoneidad & Vídeo & $\begin{array}{c}\text { Código } \\
\text { YouTube }^{\mathrm{TM}}\end{array}$ & Vistas & Idoneidad \\
\hline 01 & NEk9UaH4NBQ & 213,161 & 4 & 17 & J0VyU_k6Tz0 & 4,958 & 4 \\
\hline 02 & NfIOcg9cwKo & 97,407 & 9 & 18 & 1uAbIb-McLo & 4,916 & 7 \\
\hline 03 & 0Z5DejetHR8 & 67,768 & 20 & 19 & KgI4ypIGw_Q & 4,156 & 7 \\
\hline 04 & ulHmENICo5U & 51,454 & 7 & 20 & 12g4LRTmpoc & 3,984 & 6 \\
\hline 05 & Pr0ZIetq7wI & 50,393 & 10 & 21 & W_4X-n6gV1U & 3,969 & 20 \\
\hline 06 & $\mathrm{Cml}$ CshZu2g & 16,835 & 18 & 22 & 4FFHFYc1lak & 3,152 & 6 \\
\hline 07 & BSIABrV2ZeM & 16,196 & 17 & 23 & f8Y09YEpVOU & 2,329 & 8 \\
\hline 08 & U3eQuAiCazE & 15,976 & 17 & 24 & v8KN44iNPls & 2,326 & 5 \\
\hline 09 & 3zyBUJQY3Xw & 15,300 & 4 & 25 & lySnkOHSzz0 & 2,260 & 2 \\
\hline 10 & OsQYTvwt4Fg & 14,126 & 10 & 26 & $5 \mathrm{cM} 3$ wefOhdA & 2,162 & 16 \\
\hline 11 & JtIdG-0fUGw & 13,999 & 17 & 27 & OLy7-TkZN1k & 1,940 & 8 \\
\hline 12 & C-ldiHn5T2U & 11,494 & 6 & 28 & b-ZV1UXlgao & 1,520 & 8 \\
\hline 13 & C1wdEwJseb8 & 9,595 & 7 & 29 & f6aAmHSbIEA & 1,371 & 5 \\
\hline 14 & 2LsYrGlI4cw & 9,049 & 7 & 30 & FRmZCewj6-Q & 1,320 & 1 \\
\hline 15 & I3Riw-w1NFE & 5,682 & 5 & 31 & ml5J9W9oS8M & 1,203 & 17 \\
\hline 16 & qJDDpFHpJxA & 5,065 & 10 & & & & \\
\hline
\end{tabular}


solamente una de las seis facetas en que se descompone la idoneidad de una secuencia de enseñanza-aprendizaje. Esto quiere decir que se han tenido en cuenta otros aspectos, como los afectivos (interés, afinidad), mediacionales (estética, duración), cognitivos o ecológicos. Además, los vídeos han sido analizados de forma aislada, sin considerar la hipotética unidad didáctica en la que podrían enmarcarse. Así, habría vídeos pobres epistémicamente que podrían resultar idóneos, en cierta forma, si su duración fuera breve (idoneidad mediacional) o si describen un procedimiento cuyos significados se explicitan en otro momento (idoneidad cognitiva y ecológica). En cualquier caso, es conveniente observar que en este trabajo ha quedado patente que los criterios de idoneidad, en cuanto principios (Breda, Font, \& Pino-Fan, 2018), no tienen un carácter dicotómico o binario, sino que son graduales.

Respecto al uso de la idoneidad didáctica, como constructo teóricometodológico aplicado a posteriori, se revela como una herramienta útil y operativa para este tipo de estudio, en la misma línea de los aportes de Santos (2018).

La conclusión más directa de nuestro estudio se alinea con la de otros autores, como Jones and Cuthrell (2011), quienes claman por la necesidad de seleccionar de forma crítica los vídeos con valor educativo. Desde el punto de vista de la didáctica específica de las matemáticas, es de vital importancia que sean los propios docentes los que recomienden los vídeos idóneos para su alumnado (Ruiz-Reyes et al., 2017; Santos, 2018), por varios motivos:

- Algunos de los vídeos muestran procedimientos formalmente incorrectos.

- No todos los vídeos indican el nivel educativo al que se dirigen.

- Los significados puestos en juego en el vídeo pueden no estar en consonancia con lo que se está tratando en clase.

- La mayor popularidad de un vídeo no es indicativa de su idoneidad.

Ahora bien, también es cierto que se deberían poner en marcha acciones para desarrollar la competencia de análisis de los docentes cuando se trata de valorar estos vídeos o cualquier otro recurso (Giacomone, Godino, \& Beltrán-Pellicer, 2018).

\section{Acknowledgements / Agradecimentos}

This study has been carried out within the project EDU2016-74848-P (FEDER, AEI), of the FQM-126 Group (Regional Government of Andalusia) and within the S36_17D — Research in Mathematics Education group (Government of Aragon and European Social Fund). / Esta investigación se ha desarrollado dentro del proyecto EDU2016-74848-P (FEDER, AEI), del Grupo FQM-126 (Junta de Andalucía) y dentro del grupo S36_17D - Investigación en Educación Matemática (Gobierno de Aragón y Fondo Social Europeo).

\section{Disclosure statement}

No potential conflict of interest was reported by the authors / Los autores no han referido ningún potencial conflicto de interés en relación con este artículo. 


\section{ORCID}

Pablo Beltrán-Pellicer (iD http://orcid.org/0000-0002-1275-9976

Belén Giacomone (iD http://orcid.org/0000-0001-6752-2362

María Burgos (D) http://orcid.org/0000-0002-4598-7684

\section{ORCID}

Pablo Beltrán-Pellicer (D) http://orcid.org/0000-0002-1275-9976

Belén Giacomone (D) http://orcid.org/0000-0001-6752-2362

María Burgos (D) http://orcid.org/0000-0002-4598-7684

\section{References / Referencias}

Aguilar, M., Navarro, J.-I., \& Alcalde, C. (2003). El uso de esquemas figurativos para ayudar a resolver problemas aritméticos. Cultura y Educación, 15, 385-397.

Arguedas, C. A., \& Herrera, E. W. (2016). Implementación de un canal en YouTube para apoyar un curso Física. Atenas, 34(2), 55-67. Retrieved from https://atenas.reduniv. edu.cu/index.php/atenas/article/download/198/375

Arnal-Bailera, A., Muñoz-Escolano, J. M., \& Oller-Marcén, A. M. (2016). Caracterización de las actuaciones de correctores al calificar pruebas escritas de matemáticas. Revista de Educación, 371, 31-55.

Ben-Chaim, D., Keret, Y., \& Ilany, B. S. (2012). Ratio and proportion. Rotterdam: Sense Publishers. doi:10.1007/978-94-6091-784-4

Borba, M. C., Askar, P., Engelbrecht, J., Gadanidis, G., Llinares, S., \& Aguilar, M. S. (2016). Blended learning, e-learning and mobile learning in mathematics education. ZDM, 48, 589-610.

Bortoliero, S. T., \& León, B. (2017). El rigor científico en el vídeo online. La percepción de los expertos sobre los vídeos de contaminación del aire en YouTube. Observatorio (OBS*) Journal, 11(3), 106-119.

Breda, A., Font, V., \& Pino-Fan, L. (2018). Criterios Valorativos y Normativos en La Didáctica de las Matemáticas: El Caso del Constructo Idoneidad Didáctica. Bolema. Boletín de Educación Matemática, 32, 255-278.

Breda, A., Pino-Fan, L., \& Font, V. (2017). Meta didactic-mathematical knowledge of teachers: Criteria for the reflection and assessment on teaching practice. EURASIA Journal of Mathematics Science and Technology Education, 13, 1893-1918.

Burgos, M., Giacomone, B., Beltrán-Pellicer, P., \& Godino, J. D. (2017). Reconocimiento de niveles de algebrización en una tarea de proporcionalidad por futuros profesores de matemáticas de secundaria. In J. M. Muñoz-Escolano, A. Arnal-Bailera, P. Beltrán-Pellicer, M. L. Callejo, \& J. Carrillo (Eds.), Investigación en Educación Matemática XXI (pp. 185-194). Zaragoza: SEIEM. Retrieved from http://www.seiem.es/docs/actas/21/ActasXXISEIEM.pdf

Camacho, J. G., \& Alonso, A. J. (2010). The low interaction of viewers in Internet videos. Case study: Spanish YouTube. Revista Latina de Comunicación Social, 65, 421-435.

Davies, R. S., Dean, D. I., \& Ball, N. (2013). Flipping the classroom and instructional technology integration in a college-level information systems spreadsheet course. Educational Technology Research and Development, 61, 563-580.

De Bock, D., Verschaffel, L., \& Janssens, D. (1998). The predominance of the linear model in secondary school students' solutions of word problems involving length and area of similar plane figures. Educational Studies in Mathematics, 35, 65-83.

Giacomone, B., Godino, J. D., \& Beltrán-Pellicer, P. (2018). Desarrollo de la competencia de análisis de la idoneidad didáctica en futuros profesores de matemáticas. Educação e Pesquisa, 44, 1-26. 
Godino, J. D. (2013). Indicadores de idoneidad didáctica de procesos de enseñanza y aprendizaje de las matemáticas. Cuadernos de Investigación y Formación en Educación Matemática, 8(11), 111-132. Retrieved from http://www.centroedumate matica.com/Cuadernos/CuadernosCompletos/Cuaderno11.pdf

Godino, J. D., Aké, L., Gonzato, M., \& Wilhelmi, M. R. (2014). Niveles de algebrización de la actividad matemática escolar. Implicaciones para la formación de maestros. Enseñanza de las Ciencias, 32(1), 199-219.

Godino, J. D., Batanero, C., \& Font, V. (2007). The onto-semiotic approach to research in mathematics education. ZDM, 39, 127-135.

Godino, J. D., Neto, T., Wilhelmi, M. R., Aké, L., Etchegaray, S., \& Lasa, A. (2015). Niveles de algebrización de las prácticas matemáticas escolares. Articulación de las perspectivas ontosemiótica y antropológica. Avances de Investigación en Educación Matemática, 8, 117-142. Retrieved from http://www.aiem.es/index.php/aiem/article/view/105

Jones, T., \& Cuthrell, K. (2011). YouTube: Educational potentials and pitfalls. Computers in the Schools, 28, 75-85.

Lamon, S. (2007). Rational number and proportional reasoning. Toward a theoretical framework for research. In F. K. Lester (Ed.), Second handbook of research on mathematics teaching and learning (Vol. 1, pp. 629-667). New York, NY: Information Age Pub Inc.

Learning Mathematics for Teaching Project. (2011). Measuring the mathematical quality of instruction. Journal of Mathematics Teacher Education, 14, 25-27.

Lundberg, A. L., \& Kilhamn, C. (2016). Transposition of knowledge: Encountering proportionality in an algebra task. International Journal of Science and Mathematics Education, 1-21. doi:10.1007/s10763-016-9781-3

Márquez, J. C. (2002). Elaboración de tutoriales multimedia para el aprendizaje de conceptos estadísticos. XXI Revista de Educación, 4, 291-297. Retrieved November 7, 2017, from https://goo.gl/1hmqZN

Martínez, S., Muñoz, J. M., Oller, A. M., \& Ortega, T. (2017). Análisis de problemas de proporcionalidad compuesta en libros de texto de 20 de ESO. Revista Latinoamericana de Investigación en Matemática Educativa, 20, 95-122.

Martínez, S., Muñoz, J. M., Oller, A. M., \& Pecharromán, C. (2015). Una propuesta innovadora para la enseñanza de la proporcionalidad aritmética en el primer ciclo de ESO. In Consejería de Educación de la Junta de Castilla y León (Ed.), Congreso: Las nuevas metodologías en la enseñanza y el aprendizaje de las Matemáticas (pp. 459470). Segovia: Junta de Castilla y León.

Novo, M. L., Alsina, A., Marbán, J. M., \& Berciano, A. (2017). Inteligencia conectiva para la educación matemática infantil. Comunicar, 25(52), 29-39.

Planas, N. (2005). El papel del discurso en la construcción del Discurso de la práctica matemática. Cultura y Educación, 17, 19-34.

Ramírez, A. (2010). YouTube ${ }^{\mathrm{TM}}$ y el desarrollo de la competencia matemática: Resultados de una investigación cuasiexperimental. Contextos Educativos, 13, 123-140.

Ruiz-Reyes, K., Contreras, J. M., Arteaga, P., \& Oviedo, K. (2017). Análisis semiótico de videos tutoriales para la enseñanza de la probabilidad en educación primaria. In $\mathrm{J}$. M. Contreras, P. Arteaga, G. R. Cañadas, M. M. Gea, B. Giacomone, \& M. M. López-Martín (Eds.), Actas del Segundo Congreso International Virtual sobre el Enfoque Ontosemiótico del Conocimiento y la Instrucción Matemáticos (pp. 1-11). Granada: Universidad de Granada.

Santos, J. A. (2018). Valoración de video tutoriales de matemáticas disponibles en internet. Nuevos instrumentos para el análisis de los procesos educativos (Doctoral dissertation). Ciudad de México: Centro de Investigación y de Estudios Avanzados del Instituto Politécnico Nacional.

Tan, E. (2013). Informal learning on YouTube ${ }^{\mathrm{TM}}$ : Exploring digital literacy in independent online learning. Learning, Media and Technology, 38, 463-477. 
Turney, C. S. M., Robinson, D., Lee, M., \& Soutar, A. (2009). Using technology to direct learning in higher education. The way forward? Active Learning in Higher Education, 10, 71-83. 